\title{
Cronică
}

\section{Conferința Internațională Erasmus \\ „Dialogul interreligios şi Etica în postmodernitate”, 18 - 19 iunie 2015, Bamberg (Germania)}

\section{Ioan FILIMON}

În perioada 18 - 19 iunie a.c., la Universitatea „Otto-Friedrich” din Bamberg (Germania) a avut loc Conferința Internațională Erasmus intitulată „Dialogul Interreligios şi Etica în postmodernitate”. Eveniment științific și misionar deopotrivă, conferința internațională a fost organizată de Prof. dr. habil. Daniel Munteanu, profesor al Facultăţii de Ştiinţe Umaniste al Universităţii „Otto-Friedrich” din Bamberg şi profesor asociat al Facultăţii de Teologie a Universităţii Valahia din Târgoviște, în colaborare cu Centrul de Studii Interreligioase al universității amintite.

Manifestarea academică a debutat joi, 18 iunie prin rostirea câtorva alocuțiuni, în urma cărora moderatorul conferinței, Prof. Daniel Munteanu a prezentat programul evenimentului, invitând la dezbateri academice prin analiză critică pe toţi participanţii, prin aceasta subliniind faptul că discuțiile teologice actuale au un rol foarte important în dezvoltarea cercetării teologice.

Lucrările în plen s-au desfăşurat în sala de conferinţe a Centrului de Studii Interreligioase, unde gazda evenimentului, Prof. Dr. Thomas 
Wabel, după urarea de bun-venit participanţilor la reuniunea culturală, a dezvoltat câteva idei despre noțiunea de postsecularism.

Seria prelegerilor a fost deschisă de oaspeții de la Alba Iulia: Pr. prof. univ. dr. Mihai Himcinschi, Directorul CSUD al Universităţii ,,1 Decembrie 1918” din Alba Iulia, cu comunicarea „Martyria creștină în postmodernitate", în care a subliniat rolul misiunii în diferite sisteme politice şi de Pr. prof. univ. dr. Emil Jurcan, decanul Facultăţii de Teologie Ortodoxă din Alba Iulia, care a prezentat „Un studiu comparativ între Euharistie și alimentele sacre ale religiilor lumii”.

În continuare Pr. prof. univ. dr. Mihai Teodorescu, de la Facultatea de Teologie din Târgoviște a vorbit despre „Etica Vechiului Testament în contextul postmodernismului", secțiunea întâi a conferinţei încheindu-se cu prelegerea Pr. lect. univ. dr. Alexandru Arion, tot de la Facultatea de Teologie din Târgoviște, care a evidențiat „Influențele hisduismului și budismului în America și Europa”.

În partea a doua a zilei, Pr. prof. Mihai Himcinschi a analizat câteva „Perspective ortodoxe pentru un dialog interreligios contemporan”, iar Pr. prof. Emil Jurcan a analizat rolul „Dialogului interreligios astăzi”. Deasemenea, Pr. prof. Mihai Teodorescu a vorbit despre „Sacralitatea vieții și societatea creștină postmodernă”, ziua încheindu-se cu prelegerea Pr. lect. Alexandru Arion despre „Dialogul creștino-hindus".

Cea de-a doua zi a conferinței a fost deschisă de Prof. dr. Henrik Simojoki, de la Universitatea „Otto-Friedrich” din Bamberg, care în prelegerea sa a scos în evidență cauzele secularismului actual. În continuare, s-au dezbătut teme ca: „Misiunea creștină astăzi”; „Profetismul și intoleranța religioasă”, precum și „câteva aspecte ale metafizicii budiste".

O contribuție aparte în cadrul evenimentului, aparține Prof. Daniel Munteanu, care în prelegerea sa: „Pnevmatologie universală sau însemnătatea antropologiei harului pentru dialogul interreligios", a susținut ideea că misiunea creștină trebuie să fie o ,Cincizecime perpetuă”, o „Pogorâre a Duhului Sfânt în istorie”, o „,epicleză după epicleză", acest lucru realizându-se prin păstrarea focului Cincizecimii in dialog. 
Finalul manifestării academice a fost rezervat doctoranzilor teologi de la Şcoala Doctorală de Teologie a Universităţii „1 Decembrie 1918" din Alba Iulia, reprezentată de: Pr. Cosmin Lazăr, Andrei Dîrlău și Ioan Filimon, care au adus spre prezentare cercetarea lor academică din cadrul bursei de studiu Erasmus de la Universitatea „Otto-Friedrich" din Bamberg, primind la final criticile, sugestiile şi încurajările cuvenite din partea profesorilor îndrumători de doctorat și nu numai.

S-au prezentat apoi concluziile privind conţinutul ştiinţific dezbătut în cadrul manifestării academice, evidenţiindu-se rolul teologiei ortodoxe în societatea actuală şi faptul că Biserica este chemată să contribuie la o spiritualizare a vieţii şi la o slujire socială mai accentuată.

Referatele susținute la această conferință internațională, desfășurată la Bamberg vor fi publicate în International Journal of Orthodox Theology (IJOT), avându-l ca editor șef pe Prof. Daniel Munteanu.

Deosebitul eveniment s-a încheiat cu vizitarea universităţii şi a obiectivelor turistice din frumosul oraș medieval Bamberg, sub ghidajul şi însoţirea organizatorului.

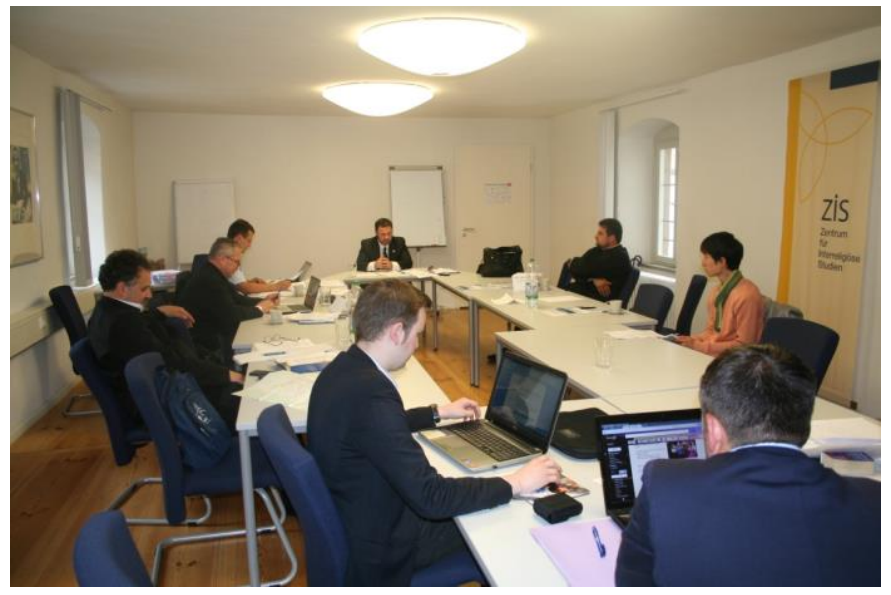


